\title{
New IGCP Projects accepted in 2005
}

\author{
Project No.506 Marine and Non- \\ marine Jurassic
}

Full Title: Marine and Non-marine Jurassic: Global correlation and major geological events

Countries involved: Argentina, Australia, Myanmar, China, Denmark, France, Germany, Hungary, India, Japan, Malaysia, Mongolia, Morocco, The Netherlands, New Zealand, Poland, Romania, Russia, Switzerland, Thailand, UK, USA, Viet Nam.

Proposers: Jingeng Sha (China), Nicol Morton (France), W.A.P. Wimbledon (UK), Paul E. Olsen (USA), Alberto G. Riccardi (Argentina), Grzegorz (Gregory) Pieñkowski (Poland), Yongdong Wang (China)

Duration: 2005-2006 (2009)

Contact Address: Prof. Dr. Jingeng Sha,

Nanjing Institute of Geology and

Palaeontology, Chinese Academy of Sciences, Nanjing 210008, P. R. China, Tel: +86-25-8328 2101, Fax: +86-25-

87714437,E-mail: jgsha@nigpas.ac.cn

The Jurassic is an important period in the earth's history and for the evolution of life. It covers about 55-60 Ma time-span and encompasses some of the most significant global events in geological history, including mass extinctions, climate and sea level changes, volcanic activities, atmospheric $\mathrm{CO}_{2}$ concentration, biodiversity change and the variation of marine and non-marine ecosystems. In particular, the Jurassic deposits in Europe, the Middle East and East Asia are the major formations for hydrocarbon resources (including coal, oil and gas), showing significant value for world's energy and mineral resources. Rich and diverse fossils have been recorded in both marine and non-marine sequences. Analysis of the biodiversity variation of such important fossil organisms is crucial for global correlation between marine and non-marine Jurassic deposits. In addition, volcanic rocks (especially tuffs) are also developed in the Jurassic of some areas. Significant work on marine/ non-marine Jurassic has been carried out in England, USA, Argentina, China and India, especially the boundaries with the Triassic and Cretaceous have long been debated and not yet been resolved on a global scale. Furthermore, our knowledge is still limited regarding to the major geological events as well as their record and potential correlation that happened during the Jurassic interval. Therefore, an international project is neces- sary to unify the geologists and palaeontologists worldwide who are interested in the studies of the Jurassic system, with emphasis upon multidisciplinary integration. The project will use the integrated multidisciplinary methods, including palaeontological, lithostratigraphical, biostratigraphical, sequence stratigraphical, lithological including volcanic, sedimentary and sedimentological, geochemical, isotopic dating and geophysi$\mathrm{cal}$, to solve the interrelated problems of correlation between marine and non-marine Jurassic, including the boundary intervals .

The aims of the project are:

1) to highlight and emphasize the importance of marine and non-marine Jurassic for understanding the evolutionary trends of both life and earth history;

2) to provide a forum for enhancing international cooperation for geologists and paleontologists who are interested in the Jurassic System;

3) to promote and produce a series of research results for the Jurassic system using a multidisciplinary approach;

4) to help improve public education for a complete and good understanding of the whole Jurassic world, including the Jurassic dinosaurs.

Project No. 508 Volcano, Collapse and Fault Activity - "Young Scientists Project"

Full title: Inception of Volcano Collapses by Fault Activity: examples from Argentina, Ecuador and Italy

Countries involved: Argentina, Ecuador, Italy, Mexico

Proposers: I. Alejandro Petrinovic (Argantina), T. Toulkeridis (Ecuador), A. Concha Dimas (Mexico), Claudia Corazzato (Italy)

Duration: 2005-2007 (three years)

Contact Address: Ivan Alejandro Petrinovic, Leon Gieco 405, 4401, Vaqueros, Salta, Argentina, Phone: 54387425 5441,

Fax: 54387425 5441,

E-mail: petrino@unsa.edu.ar

This project is aimed at understanding the influence of basement faults and their activity on volcano structural evolution in different tectonic settings, and in particular to assess the role of this influence in triggering edifice lateral collapse. This is one of the most hazardous phenomena in volcanic environment, for the volume and the mobility of the material involved, the velocities reached and the capacity of triggering violent explosive blasts or, at island volcanoes, tsunamis.
After the catastrophic collapse of Mt. S. Helens' flank in 1980, evidences of past lateral collapses have been recognized at many other volcanoes in the world, both active and extinct, and authors have proposed different possible causes of volcano deformation and failure. Among these, quite recent works have pointed out how tectonic faulting can influence volcano stability, even at extinct edifices. Moreover, although collapse phenomena are extensively documented, only recently have studies begun to quantify material properties and conditions preceding catastrophic failures. Three case sites have been chosen, Cotopaxi (Ecuador), Stromboli (Italy) and Quevar (Argentina), representative of volcanoes with evidences of past flank collapses and in close relation to faults in tectonic settings with different styles of faulting: reverse, normal and strike-slip. New contributions to the understanding of the relationship between fault activity and volcano collapse will be reached only through a strong interdisciplinary approach, by means of field, laboratory and theoretical methods. In particular, the project will foster close cooperation and enhance dialogue among field geologists experienced in volcanoes and basement structures, engineering geologists and modellists. The expected results will consist in a better understanding of the geological characteristics and processes of volcano-basement interaction, and particularly in the improvement of models describing the mechanics of large-scale volcano sector collapse controlled by the activity of faults with different kinematics. These results will also contribute to hazard and risk assessment, and the definition of possible patterns of precursor geological signals of volcano failure will be useful for monitoring planning and management, especially in developing countries. Training of young scientists and students at different levels through their involvement in research activity will lead to an improvement of preparedness of those who will have to assess volcanic hazard in the future, and will encourage them to establish a network for future international co-operative projects within and even beyond the framework of IGCP.

\section{Project No.509 Palaeoproterozoic} Supercontinents and Global Evolution

Full Title: Palaeoproterozoic Supercontinents and Global Evolution: A complete tectonic cycle representing the evolving core, mantle, lithosphere, hydrosphere, atmosphere, and biosphere

Countries involved: Australia, Botswana, Burkina Faso, Brazil, Cameroon, Canada, China, Denmark, Finland, France, Germany, India, Japan, Korea, Namibia, Nigeria, Romania, Russia, South Africa, Sweden, Tanzania, UK, USA, Zimbabwe. Proposers: S.M. Reddy (Australia), R.

Mazumder (India), D. A. D. Evans (USA) Duration: 2005-2009 
Contact Address: Dr Steven M. Reddy,

Dept. of Applied Geology, Curtin University of Technology, GPO Box U1987,

Perth, WA 6845, AUSTRALIA, Tel: +61

89266 4371, Fax: +61 892663153 ,

E-mail: S.Reddy@curtin.edu.au

The Palaeoproterozoic Era (2500-1600 Ma) is a critical period of Earth history in which it is thought that "modern" plate tectonic processes overtook the "plume" driven tectonism of the Archaean, the geodynamo gained in strength, atmospheric oxygen increased, glaciations engulfed the tropics, large changes in carbon cycling occurred, the planet suffered its two largest recorded bolide impacts, and eukaryotic life evolved from prokaryotic ancestors. Several lines of geological evidence suggest the existence of two successive supercontinents, Kenorland and Nuna, bracketing this globally important Palaeoproterozoic time interval. The amalgamation and dispersal of these supercontinents provides a framework that links processes of the deep Earth with those of its fluid veneer. This IGCP project seeks to generate plausible, quantitative reconstructions of these supercontinents, establish a thorough and robust tectono-stratigraphic synthesis of the Palaeoproterozoic geological record, and correlate supercontinental amalgamation or dispersal events with momentous changes in the Earth's geophysical, hydrological, atmospheric, and biological evolution. The project will bring together scientists from at least twenty countries, from different geological disciplines with expertise in different Palaeoproterozoic regions, and from academia, government, and industry, to develop a global view of the Earth during this critical period of planetary transition.

\section{Project No. 510 A-type Granites and Related Rock through Time}

Full title: Global Correlation of A-type Granites and Related Rocks, their Mineralization, and Significance in Lithospheric Evolution

Countries and regions involved: Australia, Belgium, Brazil, Cameroon, China, France, Finland, Japan, Norway, Russia, South Africa, Sweden, Taiwan (China), United Kingdom, United States.

Proposers: Roberto Dall'Agnol (Brazil), Carol D. Frost (USA), O. Tapani Rämö (Finland)

Duration: 2005-2009

Contact Address: Prof. O. Tapani Rämö, Department of Geology, P.O. Box 64, FI00014 University of Helsinki, Finland, Tel: +358-9-191-50810, Fax: +358-9191-50826,

E-mail: tapani.ramo@helsinki.fi

The general aim of the project is to correlate the petrology, geochronology, geochemistry, and metallogeny of A-type granites found in various tectonic settings through the geologic time. Specific themes that will be scrutinized include (1) age distribution, petrotectonic associations, and genetic models of A-type granites and related rocks; (2) their significance in metallogeny; (3) their bearing on granite typology and evaluation of hitherto proposed classifications; (4) their overall role in the evolution of the Earth's lithosphere.

Results expected:

a) Theoretical sciences. The main theoretical results will be the correlation of A-type granites and related rocks between different continents and geotectonic environments and their evolution through the geologic time. These will contribute profoundly to the understanding of granite petrogenesis and the classification of granitic rocks in general.

b) Applied sciences and technology. The main applied results will be deepened understanding of the relationships of granite petrogenesis, role of oxygen fugacity, and nature of hydrothermal processes, and different types of metallogenic provinces and deposits. This will lead to improvement of prospective and exploration strategies for economically valuable deposits.

c) Benefits to society. A-type granites are a relatively recently recognized granite group and their full potential in terms of, e.g., metal exploration and assessment of semi-precious and precious stones is not known. A-type granites have been shown to be sources of many valuable commodities (e.g., Sn, F, Nb, Au, Ag, U, rare earth elements, etc.) and better knowledge in this field will be highly beneficial to society. It is important to bridge the gap between the scientific results and their application by government and mining companies and other independent organizations to optimize the financial investment in the mineral sector and, consequently, contribute to adequate social and economic development of the developing countries in particular. The first-order societal benefits will be two-fold. First, the applied results will help certain countries to find and develop better economic resources. This will build on uniting independent working groups with state-of-theart facilities to the scientific study of granite as tools in exploration and resource assessment. This, in turn, will lead to better comprehension and use of scientific results for understanding mineralized granite systems, their genesis, exploration models, and environmental impact. Second, involvement of participants from developing countries as active partners with participants from more developed countries will enable the former to deepen their research capabilities and backgrounds, thus enabling them to become more productive scientists in their own countries. To enhance human resources is a prime aspect of the project and will be a direct result of collaborative research and involvement of students. Comprehensive accomplishment of the second benefit will be reached through collaborative research projects.
Project No.511 Submarine Mass Movements and their Consequences

Full title: Submarine Mass Movements and their Consequences

Countries involved: Australia, Belgium, Brazil, Canada, Germany, France, Georgia, Greece, China, Italy, Japan, Netherlands, New Zealand, Norway, Portugal, Spain, Switzerland, UK, USA.

Proposers: Jacques Locat (Canada), Juergen Mienert and Roger Urgeles-(IOC link) Duration: 2005-2009

Conctact Address: Jacques Locat, Department of Geology and Geological Engineering, Laval University, Québec, Qc, Canada, G1K 7P4, Tel: 14186562179 , Fax: 14186567339 ,

E-mail: locat@ggl.ulaval.ca

The Grand Banks earthquake of 1929 triggered a huge submarine mass movement which broke submarine cables over a distance of up to $1000 \mathrm{~km}$ from its source and generated a tsunami which devastated small villages in Newfoundland killing 27 people. A similar event happened in Papua New Guinea in 1998 with more than 2000 casualties. Submarine mass movements of various sizes and styles are shaping the sea floor and are of concern for many facets of human activities both onshore and offshore. These include the development of natural resources, energy and communication transport, coastal infrastructures and communities. This IGCP project will bring a worldwide perspective to submarine mass movements and their consequences. Such a perspective will be made possible by assembling excellent contributions from active researchers, groups or institutions thus providing a full coverage of the many scientific and engineering aspects of this type of marine and coastal geo-hazard. It will cover fundamental as well as site specific studies from many areas including the Atlantic and Pacific oceans, inner seas like the Mediterranean Sea, fjords and lakes using the most recent technologies from multibeam sonar imaging and 3D seismic, stability analysis, to debris flow and tsunami modeling.

\section{Project No.512 Neoproterozoic Ice Ages}

Full title: A New Global Synthesis on NeoProterozoic Ice Ages, their Correlation, Ages, Duration, Areal Extent, Geological Setting, Related Ore Genesis, Causes and Effects

Countries involved: Argentina, Australia, Austria, Brazil, Burkina Faso, Canada, China, France, Germany, India, Iran, Japan, Mali, Mauritania, Mexico, Mongolia, Norway, Russia, Senegal, South Africa, Sweden, Switzerland, UK, Uruguay, USA

Proposers: Emmanuelle Arnaud (Canada), Marly Babinski (Brazil), Yves Goddéris (France), Galen Halverson (France), Mar- 
tin Kennedy (USA), Conall Mac Niocaill (UK), Vibhuti Rai (India), Graham Shields (Australia), Maoyan Zhu (China) Duration: 2005-2009

Contact Address: Dr Graham Shields,

School of Earth Sciences, James Cook

University, Townsville, Queensland

4811, Australia, Tel (work): +61 (7) 4781

5008, Fax: +61 (7) 4725 1501,

E-mail: graham.shields@jcu.edu.au

Over the last decade there has been a growing recognition that the Earth possibly witnessed its most extreme climatic fluctuations during the mid-late Neoproterozoic between $\sim 750 \mathrm{Ma}$ and $\sim 550 \mathrm{Ma}$. Indeed, there is compelling but controversial evidence that glaciers even reached the equator around $635 \mathrm{Ma}$ inspiring the evocative visual metaphor of the Snowball Earth. Mounting evidence suggests that there might have been three or more distinct glacial episodes during this 200 million year interval of Earth history. However, there is currently no consensus regarding the number or relative severities of these ice ages, while their implications for biotic evolution awaits a firmer understanding of global stratigraphic correlation. By integrating proven expertise among emerging researchers worldwide from eight different subdisciplines within geoscience, we aim to work towards a consensus global stratigraphic calibration scheme for the mid-late Neoproterozoic and an authoritative global synthesis of Neoproterozoic climate change. Questions to be addressed are:

1. How many distinct glacial episodes occurred during the Neoproterozoic era?

2. When did each glacial episode occur?

3 . How long did each glacial episode last?

4. Can we use Neoproterozoic glacial sediments and their related marker beds, such as cap carbonates, for global stratigraphic correlation and subdivision?

5 . What was the areal extent of each glacial episode?

6. What was the tectonic and palaeogeographic setting of each glacial episode?

7. What were the likely effects of Neoproterozoic glaciation on atmospheric, oceanic and lithospheric changes and biotic evolution?

8. When and how did cap carbonates form?

9. When and how did related ore deposits (sedimentary iron formations, manganese formations, barite, phosphorites and U-, $\mathrm{V}-$, Pt-, Au-ferous black shales) form?

10. To what extent do current hypotheses of Neoproterozoic glaciation and its causes and effects fit the geological evidence for each glacial episode?

These questions will be addressed primarily by collaborative fieldwork in key Neoproterozoic successions in over ten different countries (current collaborative work among participants is taking place in Oman, Namibia, and Canada, while future IGCP work will take place in Senegal, Burkina Faso, Russia, Brazil, UK, China, Norway,
Russia, Australia, and USA) over five years and related laboratory work in over ten different countries. The results of this project will advance the science of Earth System evolution and lead to a better understanding of past global climate change and its effects on ore deposition and faunal evolution.

\section{Project No.513 Karst Aquifers and Water Resources}

Full title: Global Study of Karst Aquifers and Water Resources

Countries involved: Austria, Australia, Belgium, Brazil, China, Croatia, Czech Republic, Egypt, France, Germany, Indonesia, Iran, Italy, Japan, Jordan, Lebanon, Mexico, New Zealand, Philippines, Puerto Rico, Russia, Serbia and Montenegro, Slovenia, South Korea, Spain, Switzerland, Syria, Turkey, Ukraine, United Kingdom, United States, Venezuela, Vietnam.

Proposers: Chris Groves (USA), Yuan Daoxian (China), Bartolome AndreoNavarro (Spain), Heather Viles (UK)

Duration: 2005 (-2009)

Contact Address: Chris Groves, Hoffman

Environmental Research Institute, Department of Geography and Geology, Western Kentucky University, Bowling Green, Kentucky 42101, USA, Tel: +1 270745 5974, Fax: +1 2707456410 ,

E-mail: chris.groves@wku.edu

This project is proposed as the successor to Project 448: World Correlation of Karst Geology and Relevant Ecosystems, approved by the IGCP Scientific Board in 2000 , and which published its final report in 2004. Project 448 is the most recent of three successful karst-related projects carried out under the auspices of IGCP, which also included Project 299: Geology, Climate, Hydrology and Karst Formation (1990-1994) and Project 379: Karst Processes and the Global Carbon Cycle (1995-1999).

An irony is that many of the world's significant karst areas occur in poorly developed economic regions, in part due to the physical challenges that these landscapes often present with regard to water supply, agriculture, and urban development. Thus, resources are often limited to address these significant problems. The main purpose of the proposed project is to encourage international cooperation to increase understanding of karst water resources with regard to both ecological and human health concerns, and to promote the sharing of ideas, experiences and resources in developing solutions to karst water resource challenges. We propose a transdisciplinary approach to address the four major areas of emphasis for the project:

1) Relation of hydrology to the function and health of karst ecosystems;

2) Water supply in karst regions;

3) Water-related environmental problems in karst regions;
4) Aqueous geochemistry of karst aquifer/ landscape systems.

Project No. 514 Fluvial Palaeosystems: Evolution and Mineral Deposits

\section{Full title: Tectonically and Climatically} Induced Evolution of Fluvial Palaeosystems and Applications to Mineral Exploration

Countries involved: Australia, Byelorussia, Canada, China, India, Israel, Mongolia, Russia, Uzbekistan, Ukraine, USA.

Proposers: Prof. Natalia Patyk-Kara (Russia), Dr. Alejandra Duk-Rodkin (Canada), Dr. Baohong Hou (Australia), Prof.

Ziyang Li (China), and Dr. Vladimir Dolgopolov (Kazakhstan)

Duration: 2005-2009

Contact Address: Prof. Natalia Patyk-Kara, Institute of Geology of Ore Deposits, Petrography, Mineralogy and Geochemistry, (IGEM) of Russian Academy of Sciences, Staromonetny per., 35, Moscow 119017 ,

Russia, Tel: (7095) 2308427 ,

Fax: (7-095) 2302179 ,

E-mail:pkara@igem.ru

The main aim of this project is to analyse palaeo-fluvial channels in environments where mineral deposits are found. These include proximal gravel accumulations (placer gold, PGE, tin, rare metals, etc.), distal gravel and sand accumulations (diamonds, heavy minerals, fine gold, etc.), and hydrogenic (leached) deposits related to (occurring on) complex geochemical barriers (uranium and attendant molybdenium, rhenium, selenium, yttrium, rare elements, etc.). These sedimentary ore accumulations are known to occur in palaeovalleys, palaeochannels and palaeoshorelines of various ages from Recent to Pre-Cambrian (Tertiary, Cretaceous, Jurassic, Carboniferous, Devonian, Vendian, Riphean, etc.). The critically important objective is an understanding of the dynamics of palaeochannel morphology, palaeochannel evolution and sedimentary ore accumulations related to palaeochannels. Valley and shoreline systems which have evolved during the Palaeozoic, Mesozoic, and Tertiary-Quaternary serve as models for this analysis. In particular, late Cenozoic oreenclosing drainages are model systems for better understanding the Pre-Cenozoic palaeovalley ore formation.

The methodology of the project is as follows:

1) Analysis of intercontinental-scale fluvial systems modified by plate tectonics.

2) Identification of drainage features inherited from previous stages of drainage and basin evolution:

a. Assessment of inter- and intra-valley reconfigurations affected by tectonics and climate and their influence on formation and preservation of ore accumulations. b. Assessment of palaeodrainage and palaeoshoreline interrelationships. 
c. Assessment of the controlling factors in local sedimentary traps, on geochemical barriers and in over-deepened valleys.

3) Identification of metal and mineral distributions in palaeochannel systems:

a. Climatic zonality and ore-forming processes in palaeochannels.

b. Integrated analysis of metal and mineral distributions and their comparative potential as economic deposits.

4) Detailed comparison of types of ore-bearing palaeochannel systems within regions, and between continents, by way of annual workshops.

5) Synthesis of results and publication of an edited monograph.

\section{Project No.515 Coastal Vulnerability} related to Sea Level Change

Full title: Vulnerability and Resilience Assessment of Coastal Zone in Mediterranean and Black Sea Areas Related to the Forecast Sea Level Rise for Management Purposes.

Countries involved: Albania, Algeria, Bulgaria, Croatia, Cyprus, Egypt, France, Georgia, Greece, Israel, Italy, Lebanon, Libya, Malta, Morocco, Romania, Spain, Syrian, Tunisia, Turkey, Ukraine, Russia.

Proposers: U. Simeoni (Italy), Maria Snoussi (Morocco), Zdravko Belberov (Bulgaria), François Sabatier (France) Duration: 2005-2009

Contact Address: Prof. Dr. Umberto Simeoni, Dipartimento di Scienze della Terra, Università di Ferrara, Corso Ercole I D'este, 32, 44100 Ferrara, Italy, Tel: +39 - (0)532 293723, Fax: +39 - (0)532

206468,E-mail: g23@dns.unife.it

One of the more certain consequences of global climate changes is an accelerated global sea level rise that, according to recent studies, is assumed to reach $49 \mathrm{~cm}$ in 2100 . Moreover the relative sea level rise (RSLR) is expected to be higher in coastal or deltaic zones affected by subsidence. This RSLR will increase the stress on many coastal zones, where $21 \%$ of the world's population already live within $30 \mathrm{~km}$ from the sea, in particularly costal zones where human activities have diminished natural and socio-economic adaptative capacities. The coastal zones could be affected in terms of increased erosion, inundation and displacement of coastal wetlands and other coastal lowlands, increased risk of flooding or storm damage and salinisation of surface and ground waters. These primary impacts will be on livelihoods, human health, infrastructure and economic activity. However, the quantitative assessment of climate change impacts on coastal zone is generally considered a complex task and involves a number of analytical challenges, including scientific and economic uncertainties and data limitations. The aim of this project is to bring the relevant research groups together in order to define the more common suitable methods to assess the coastal vulnerability towards future sea level rise and propose a common guideline for coastal management.

\section{Project No.516 Geological Anatomy of East and South East Asia}

\section{Full title: Geological Anatomy of East and}

South Asia: Paleogeography and Paleoenvironment in Eastern Tethys

Countries involved: Australia, Bangladesh, Brunei, China, India, Indonesia, Japan, Korea, Lao PDR, Malaysia, Myanmar, Pakistan, Philippines, Thailand.

Proposers: Ken-ichiro Hisada (Japan), Punya Charusiri (Thailand), Byung-Joo Lee (Rep .of Korea), Xiaochi Jin (China) Duration: 2005-2009

Contact Address: Dr. Ken-ichiro Hisada, Division of Earth Evolution Sciences, Graduate School of Life and Environmental Sciences, University of Tsukuba, Tennodai 1-1-1, Tsukuba, Ibaraki, Japan 305-8572, Tel \& Fax: +81-298-534300,

E-mail: hisadak@kyouiku.tsukuba.ac.jp The project is a successor to IGCP 224 (Pre-Jurassic Evolution of Eastern Asia, 1985-1990), 321 (Gondwana Dispersion and Asian Accretion, 1991-1996), and 411 (Geodynamics of Gondwanaland-derived Terranes in E \& S Asia, 1998-2003). The project aims at understanding the assembly processes of Gondwana-derived terranes and the final emplacement of these terranes into the Asian continent during the Mesozoic and Cenozoic times. The fundamental goal of this project is to gain palaeogeography and palaeoenvironment in the eastern Tethys. To achieve this purpose, the geological anatomy of East and South Asia as well as Southeast Asia will be indispensable. In previous projects, the framework of geodynamic processes has been established, but the indentification and interrelation of terranes are still controversial and the fundamental knowledge for some terranes is scarce. Moreover internal structure of some orogenic belts in the relevant area is still poorly known. Consequently, crustal evolution, rifting and collision processes and formation of natural resources in the East and South Asia will be analyzed in details within the framework of Gondwana-derived terranes in the vast region embracing Pakistan, Sri Lanka, India, Bangladesh, Myanmar, Lao PDR, Thailand, Cambodia, Vietnam, Indonesia, Brunei, Papua New Guinea, Philippine, China, Korea, Japan and the Russia Far East. The project, therefore, involves an interdisciplinary approach including igneous and metamorphic petrology, geochemistry, sedimentology, tectonics, palaeobiogeography, palaeomagnetism, geophysics, and petroleum/coal geology.

\section{Project No. 518 Fluvial Sequences as Evidence for Landscape and Climatic Evolution in the Late Cenozoic}

Full title: Fluvial Sequences as Evidence for Landscape and Climatic Evolution in the Late Cenozoic

Proposer: David Bridgland (UK)

\section{Duration: 2005-2009}

Contact Address: Department of Geography, University of Durham, South Road,

Durham DH1 3LE, United Kingdom, Tel: 44191334 1875, Fax: 44191334 1801,

E-mail: D.R.Bridgland@durham.ac.uk

The project envisages to compile a database of long fluvial sedimentary sequences (and their palaeontological and archaeological contents), enabling comparison and correlation between all parts of the globe and providing evidence of environmental change, landscape evolution and crustal movements.

Results expected:

- potential records on late Cenozoic climatic and environmental change, and landscape evolution

- provision of context for various other important research areas (e.g. mammalian evolution; human occupation and migration; tectonic history) that are studied extensively from fluviatile records;

- provision of comparative material for data from other terrestrial environments;

- provision of stratigraphical frameworks for terrestrial Quaternary research;

- provision of terrestrial sequences that can be correlated with the globally valid oceanic record of Quaternary climatic change, the oxygen isotope stratigraphy.

The project will have potential benefits in connection with the prospecting for and exploitation of (as well as conservation of) resources from fluvial sequences, such as aggregates and placer mineral deposits. It will provide improved understanding of the response of rivers to environmental and climatic change. This will be of benefit to those who have to live with and manage rivers in the widest sense, with applications for flood management schemes, irrigation and diversion schemes, navigation projects and other areas of human management and exploitation of rivers. There is also value in this type of research for understanding future global environmental change resulting from human impacts.

Project No.519 Hydrogeology, Hydrochemistry and Management of Coastal Aquifers on the Atlantic Coast of South America

Full title: Hydrogeology and Hydrochemistry in Coastal Aquifers on the Atlantic Coast of South America. Its knowledge for water management in the province of Buenos Aires, Argentina, in the state of Rio de Janeiro, Brazil and in the touristic and historic district of Santa Marta, Colombia.

Countries involved: Argentina, Brazil, Colombia.

Proposer: Emilia Bocanegra (Argentina)

Duration: 2005(-2009)

Contact Address: Emilia Bocanegra, Casilla de Correo 722 - (7600), Mar del Plata, Argentina, Tel: +54 223 4754060, Fax: +54 223 4753150, E-mail: ebocaneg@mdp.edu.ar 
The project aims at developing joint methodologies on marine intrusion process analysis in coastal aquifers on the Atlantic coast of South America, by assembling existing information and the participating research teams' potential. Activities and capacities to develop numeric models of coastal aquifer functioning which help as management tools will be undertaken.

a) In theoretical sciences: we aim at increasing knowledge of coastal aquifers systems' functioning in the Atlantic coast of South America. A joint analysis of the extensive coastal area with climatic and geological variations will allow to evaluate the effect of the different parameters on the hydrological functioning of coastal aquifers.

b) In applied sciences and technology: using numerical models in coastal aquifers' planning and management, its calibration and validation will contribute to the development of mathematical tools.

c) In respect to benefit of society: the Province of Buenos Aires and the State of Rio de Janeiro are the most populated states in South America. Their population levels are about 10 million and 20 million inhabitants respectively. The Touristic and Historic District of Santa Marta in Colombia has a population of 430,000 inhabitants and it is one of the most growing population cities in the country. These are also areas of high economic productivity in their countries. Access to safe water in quality and quantity is a vital need for human development. However, its exploitation in coastal areas is being threatened by problems derived from the salt water-fresh water interface, which is characteristic of these regions. Creating the appropriate tools for a better planning and management will benefit these two highly populated economic centers of South America.

\section{Project No. 521 Black Sea}

Mediterranean Corridor during the Last 30 ky: Sea Level Change and Human Adaptation

\section{Countries involved: Algeria, Azerbaijan,} Belgium, Bulgaria, Canada, Egypt, Finland, France, Georgia, Germany, Greece, Israel, Italy, Macedonia, Moldova, Romania, Russia, Switzerland, Turkey, UK, Ukraine, USA.

Proposers: Valentina Yanko-Hombach (Canada), Yucel Yilmaz (Turkey), Pavel Dolukhanov (UK)

Duration: 2005-2009

Contact Address: Prof. Dr. Valentina Yanko-Hombach, Avalon Institute of Applied Science, Charleswood Technology, Centre, 3227 Roblin Blvd, Winnipeg MB R3R 0C2, Canada, Tel: +1 204489 4569, Fax: +1 204489 5782,

E-mail: valyan@avalon-institute.org
The Black Sea-Mediterranean Corridor is an integrated oceanographic system defined here as the large geographical area covering the Manych-Kerch Gateway (Manych Valley, the Sea of Azov and the Kerch Strait) that lies to the east of the Black Sea, the Black Sea, the Marmara Gateway (the Bosphorus Strait, the Sea of Marmara and the Dardanelles), the Aegean Sea, the Eastern Mediterranean and their coasts. During the Late Pleistocene the "Corridor" was connected to the Caspian Sea via Manych Gateway. Today, the "Corridor" is of strategic importance not only for all coastal countries but also for at least 17 other countries sharing a drainage basin that is one-third the size of the European continent. The "Corridor" acts as a palaeoenvironmental amplifier and as a sensitive recorder for climatic events where sea level variations and coastline migration are especially pronounced due to its geographical location and semi-isolation from the open ocean. It also provides a linkage between the marine and continental realms. Over the past $30 \mathrm{ky}$, the "Corridor" underwent a complicated history, which remains hotly debated. Lately, this region has spurred a tremendous international interest as a possible place where the biblical story of the Great Flood originated, encouraging a new round of controversial research on the hydrological regime in connecting straits, transition from a lacustrine to a marine environment, an influence of the Black Sea outflow on deposition of the Eastern Mediterranean sapropels as well as past/present/ future adaptation of humans to environmental change.

The main goal of the project is to cover this gap by bringing the relevant but diverse research groups together to provide cross-disciplinary and cross-regional correlation of geological, geochemical, geophysical, palaeontological, archaeological and historical records for the entire "Corridor" in order to evaluate an influence of sea level change and coastline migration on human adaptation during last $30 \mathrm{ky}$. The research is focused on evolution of the coastal zone where a rich sedimentary, landform and archaeological archive provides a superb opportunity for studying spatial and temporal interactions between human adaptation and environmental change. This work will result in fundamental new knowledge regarding the driving mechanisms that influence human adaptation in the region that became known as the "cradle of civilization", a subject of great interest to the Quaternary, earth, marine, environmental and social sciences. Its strong applied component will be directly relevant to coastal managers in regard to the environmental risk assessment and sustainable development of the "Corridor" under Global Climate Change anticipated to take full effect in this century.

\section{Project No.522 Dawn of the Danian}

Full title: Dawn of the Danian (65-61 Ma): Post K-T Boundary Austral Biotic Survivorship and Recovery in a 'Brave New World'

Countries involved: Australia, Argentina, India, New Zealand, South Africa,

Uruguay, USA.

Proposers: Jeffrey D. Stilwell (Australia), Claudia Del Río (Argentina)

Duration: 2005-2009

Contact Addresss: Dr. Jeffrey D. Stilwell,

Palaeontology, School of Geosciences,

Monash University, Clayton VIC 3800 ,

Australia,

E-mail: Jeffrey.Stilwell@sci.monash.edu.au The Danian interval (Early Palaeocene Epoch, 65-61 Ma) of the Tertiary Period immediately followed the Cretaceous-Tertiary (K-T) boundary mass extinction event (65 Ma), one of the greatest crises throughout the entire Phanerozoic that saw the global extermination of scores of terrestrial and marine animals and plants. The organisms living at the beginning of the Tertiary heralded the onset of the modern fauna. Moreover, pioneers in this 'brave new world' were made up of survivors, opportunistic and migrant taxa, and newly evolved groups that infilled the ecological vacuum left by the mass extinction. Thus, the Danian biota was characterized by complex evolutionary histories that exhibit dramatic signatures of composition and biodiversity levels relating to extinction and post-extinction recovery processes. Of particular significance, it has come to light only recently with preliminary intense research that the composition and biodiversity patterns of Southern Hemisphere Danian organisms are proving distinct from the North, indicating that although the mechanisms driving the observed patterns may be comparable, they have, in part, a unique suite of historical attributes. Outcomes from this research on the Danian will provide important new information with links to the International Subcommissions on Cretaceous and Paleogene Stratigraphy and spin-offs related to improvement of biostratigraphic control, which is in turn useful for geological exploration and hence, industry needs.

Research on biodiversity and evolutionary processes is of utmost importance in this time of looming habitat loss and species extinctions worldwide, now accelerating at an ominous rate. Estimates based on recent documentation of shifts in the distributions and abundance of species fuelled by climate change predict that more than a million species will be extinct by 2050. In terms of magnitude of extinction, this impending tragedy facing humankind today (labelled as the "Sixth Extinction") rivals the K-T boundary mass extinction. Studying patterns of biodiversity through time via the examination of intervals of global crises to those of quiescence provides humankind with the 
ammunition to deal with and predict future trends of global biosphere change. The Danian interval in the Southern Hemisphere is a perfect case study to examine the biotic response to major environmental change.

\section{Project No.523 GROWNET - Gobal} Ground Water Network

Full title: Global Ground Water Network for Best Practices in Ground Water Management in Developing Countries. (A collaborative project between UNESCO-IGCP and expert members in two associations viz. IAH and AGID, affiliated to IUGS)

Countries involved: Argentina, Bangladesh, India, Mexico, UK, Pakistan.

Proposers: Shrikant Daji Limaye (India), Dr A J Reedman (UK)

Duration: 2005 (-2009)

Contact Address: Dr S D Limaye, Ground Water Institute, 2050 Sadashiv Peth, Pune 411 030, India, Tel: +91 2024331262 . Fax: +91202433 3535,

E-mail: limaye@vsnl.com

Ground water management includes exploration, assessment, sustainable utilization and protection of quality and quantity of ground water. In many developing countries or low income countries, ground water is getting over-exploited, polluted and scarce. However, in small watersheds in rural areas, there are a few examples of better management, through devoted work of some NGOs with participation of local people. In Urban areas, there are examples of roof water harvesting and recharging of aquifer. It is proposed under this project, to disseminate the success stories and experiences of ground water management through GROWNET website and Newsletter. It is also proposed to arrange regional meetings of the experts involved to discuss the methodologies, their success and shortcomings. The GROWNET would be an effective, transparent, authentic and gender sensitive network for Dissemination of Information and Capacity Building for following the Best Practices in Ground Water Management in South and South-East Asia, Sub-Saharan Africa and in Latin America.

\section{IGCP Secretariat}

UNESCO, Division of Ecological and Earth Sciences

1, Rue Miollis

75732 Paris Cedex 15

FRANCE

Tel: +33145684118

Fax: +33145685822

E-mail:igcp@unesco.org

\section{IGCP Projects 2005}

(O.E.T.-on extended term)

\section{No. 447 Proterozoic Molar-tooth Car-} bonates

Project leaders: X. Meng (China), D. G. F. Long (Canada), R. Bourrouilh (France)

Duration: 2001-2005

http://www.cugb.edu.cn/IGCP/yhtzl.html http://laurentian.ca/geology/INDEX.HTML

No. 450 Proterozoic Sediment-Hosted Base Metal Deposits of Western Gondwana

Project leaders: S.S. Iyer (Canada),

A.F. Kamona (Namibia), A. Misi (Brazil),

J. Cailteux (DR Congo)

Duration: 2000-2004 (OET)

http://www.ucalgary.ca/ iyer/igcp450/unesc o/catalog.htm

No. 455 Basement Volcanoes Interplay and Human Activities

Project leaders: A. Tibaldi (Italy), M. Garcia (Spain), A.M. Lagmay (Philippines), V.V. Ponomareva (Russia)

Duration: 2001-2005

http://www.geo.unimib.it/IGCP455.htm

\section{No. 458 Triassic/Jurassic Boundary}

Events

Project leaders: J. Pálfy (Hungary), S.P.

Hesselbo (United Kingdom), C. McRoberts (United States)

Duration: 2001-2005

http://paleo.cortland.edu/IGCP458/

No. 459 Terrestrial Carbon Cycle Project leaders: J.-L. Probst (France), L. François (Belgium), P. J. Depetris (Argentina), J. Mortatti (Brazil)

Duration: 2001-2005

http://www.omp.obs-

mip.fr/omp/umr5563/4equ/hg/IGCP459/second.html

\section{No. 463 Upper Cretaceous Oceanic Red Beds}

Project leaders: C. Wang (China), M. Sarti (Italy), R.W. Scott (United States),

L.F. Jansa (Canada)

Duration: 2002-2006

www.igcp463.cdut.edu.cn

No. 464 Continental Shelves During the Last Glacial Cycle

Project leaders: F.L. Chiocci (Italy),

A.R. Chivas (Australia)

Duration: 2001-2005

http://tetide.geo.uniroma1.it/igcp464.html
No. 467 Triassic Time and Trans-Panthalassan Correlations

Project leaders: M. J. Orchard (Canada),

L. Krystyn (Austria), J. Tong (China),

S. Lucas (United States), H. Campbell (New Zealand), F. Hirsch (Japan), K. Ishida (Japan), Y. Zacharov (Russia)

Duration: 2002-2006

http://paleo.cortland.edu/IGCP467/ index.html

http://www.bio.uu.nl/ p palaeo/Albertiana/ Albertiana01.htm

http://imbi.uwc.ac.za/courses/ifaa/petralga/ index.htm

No. 469 Variscan terrestrial Biotas and Palaeoenvironments

Project leaders: C.J. Cleal (United Kingdom), S. Opluštil (Czech Republic),

Y. Tenchov (Bulgaria), E. Zodrow (Canada) Duration: 2003-2007

http://www.mepopa.com/igcp469.htm

No. 470 The Neoproterozoic PanAfrican Belt of Central Africa Project leader: F. Toteu (Cameroon) Duration: 2002-2006 http://www.igcp470.org

No. 471 Evolution of Western Gondwana during the Late Palaeozoic Project leaders: C.O. Limarino (Argentina), L.A. Buatois (Argentina) Duration: 2002-2006

http://www.limarino.org/IGCP/Home.htm

\section{No.473 GIS Metallogeny of Central} Asia

Project leaders: R. Seltmann (United Kingdom), M. Kim (Uzbekistan), R. Bahtdavlatov (Tadjikistan)), I.G. Gurieva (Russia), A. Dolgopolova (Kazakhstan) Duration: 2002-2006

http://www.nhm.ac.uk/mineralogy/cercams/ IGCP-473.html

http://www.nhm.ac.uk/mineralogy/cercams/ index.htm

\section{No. 474 Depth Images of the Earth's} Crust

Project leaders: B.J. Drummond (Australia), L.D. Brown (United States), F.A. Cook

(Canada), O. Oncken (Germany), G.S. Fuis (United States), R.W. Hobbs (United Kingdom), Songlin Li (China), D.M. Finlayson (Australia)

Duration: 2003-2007

http://www.earthscrust.org 
No. 475 Deltas in the Monsoon AsiaPacific Region (DeltaMAP)

Project leaders: S. Goodbred, Jr. (United States), Y. Saito (Japan)

Duration: 2003-2007

http://unit.aist.go.jp/igg/rg/coast-rg/MRE.1/ ADP/ADP_en/a_igcp475_en.html

No. 476 Monsoon Evolution and Tectonic-Climate Linkage in Asia Project leaders: R. Tada (Japan), Hongbo Zheng (China), Boo-Keun Khim (Korea), P. Clift (United States), S.A. Gorbarenko (Russia), B.N. Nath (India)

Duration: 2003-2007

http://igcp.ees.hokudai.ac.jp/ 476

No. 478 Neoproterozoic-Early Palaeozoic Events in South-West-Gondwana Project leaders: C. Gaucher (Uruguay), D. Poiré (Argentina), P. C. Boggiani (Brazil), A. Braun (Germany), H. Frimmel (South Africa), J. B. Germs (South Africa) Duration: 2003-2007

Official website:

www.vssagi.com/igcp478/igcp478.htm

Related website: www.leda.fcien.edu.uy

No. 479 Sustainable Use of Platinum Group Elements

Project leaders: J. E. Mungall (Canada), M. Iljina (Finland), C. Ferreira-Filho (Brazil) Duration: 2003-2007

http://www4.geology.utoronto.ca/faculty/mu ngall/Website/IGCP479Home.htm http://platinumsymposium.oulu.fi/

No. 480 Tectonics of Central Asia Project leaders: B. Natal'in (Turkey), A. Yin (United States), A. M. C. Sengör (Turkey), M. Kuzmin (Russia) Duration: 2005 (-2009) (preliminary acceptance)

\section{No. 481 Dating Caspian Sea Level} Change

Project leaders: S. B. Kroonenberg (Netherlands), S. Leroy (United Kingdom)

Duration: 2003-2007

http://www.caspage.citg.tudelft.nl/ www.caspiansealevelchange.org

No. 482/489 Geodynamics of the East African Rift System / Geophysical Characteristics and Evolution of the Southwestern Branch of the East African Rift System

Project leaders: G. Mulugeta (Sweden)/ A. Atekwana (United States), M. P. Modisi (Botswana), M. N. Sebagenzi (D. R. Congo), J. J. Tiercelin (France)

Duration: 2003-2007

website will soon be available

No. 485 The Boundaries of the West

African Craton

Project leaders: N. Ennih (Morocco);

J-P. Liégeois (Belgium)

Duration: 2003-2007

www.igcp-485-nkc2004.mr
No. 486 Au-Ag-Telluride-Selenide Deposits

Project leaders: N. J. Cook (Norway),

K. Kojonen (Finland)

Duration: 2003-2007

www.ngu.no/igcp486

No. 487 Seismic Microzoning of Latin American Cities

Project leaders: J. L. Alvarez Gómez (Cuba), A. Giesecke (Peru), G. F. Panza (Italy)

Duration: 2004-2008

No. 490 Environmental Catastrophes Project leaders: S. Leroy (United Kingdom), I. Stewart (United Kingdom)

Duration: 2003-2007

www.brunel.ac.uk/igcp

No. 491 Middle Palaeozoic Vertebrate Biogeography, Palaeogeography and Climate

Project leaders: M. Zhu (P.R. China),

G. Young (Australia)

Duration: 2003-2007

http://paleoworld.net

No. 493 The Rise and Fall of the Vendian Biota

Project leaders: M. Fedonkin (Russia),

P. Vickers-Rich (Australia), J. Gehling

(Australia)

Duration: 2003-2007

http://www.earth.monash.edu.au/PreCSite/i ndex.html

No. 494 Dysoxic to Oxic Change in Ocean Sedimentation During the Middle Cretaceous: A Study of the Tethyan Realm - "Young Scientists Project" Project leaders: Xiumian $\mathrm{Hu}$ (China), K. Bak (Poland), J. Wendler (Germany), N. Tur (Russia)

Duration: 2003-2005 (three years)

\section{No.495 Quaternary Land-Ocean Inter-} actions

Project leaders: A. Long (United Kingdom), S. Islam (Bangladesh)

Duration: 2004-2008

\section{No. 497 The Rheic Ocean}

Project leaders: U. Linnemann (Germany), R.D. Nance (United States), M. de Wit (South Africa), E. Bozkurt (Turkey), P. Kraft (Czech Republic), F. Pereira (Portugal), R.A. Strachan (United Kingdom) Duration: 2004-2008

http://www.snsd.de/igcp497/

No. 499 Evolution of Ecosystems and Climate in the Devonian

Project leaders: P. Königshof (Germany), J. Lazauskiene (Lithuania), E. Schindler (Germany), Volker Wilde (Germany) and N. Yalçin (Turkey)

Duration: 2004-2008

http://www.senckenberg.de/igcp-499
No. 500 Dryland Change: Past, Present, Future

Project leader: D. Thomas (United Kingdom)

Duration: 2004-2008

http://www.igcp500.ouce.ox.ac.uk/ (not working)

No. 502 Global Comparison of Volcanichosted Massive Sulphide Districts Project leaders: R. Allen (Sweden), F. Tornos (Spain), J. Peter (Canada), N. Çagatay (Turkey) Duration: 2004-2008

No. 503 Ordovician Palaeogeography and Palaeoclimate

Project leaders: T. Servais (France), D.A.T. Harper (Denmark), J. Li (China), A. Munnecke (Germany), W. Owen (United Kingdom), P. M. Sheehan (United States)

Duration: 2004-2008

http://sarv.gi.ee/igcp503/

No. 506 Marine and Non-marine Jurassic Project leaders: Jingeng Sha (China), Nicol Morton (France), W.A.P. Wimbledon (UK), Paul E. Olsen (USA), Alberto G. Riccardi (Argentina), Grzegorz (Gregory) Pieñkowski (Poland), Yongdong Wang (China)

Duration: 2005-2006 (2009)

No. 508 Volcano Collapse and Fault Activity - "Young Scientists Project" Project leaders: I. Alejandro Petrinovic (Argantina), T. Toulkeridis (Ecuador), A. Concha Dimas (Mexico) Claudia Corazzato (Italy) Duration: 2005-2007 (three years)

No.509 Palaeoproterozoic Supercontinents and Global Evolution

Project leaders: S. M. Reddy (Australia), R. Mazumder (India), D.A.D. Evans (USA) Duration: 2005-2009

No.510 A-type Granites and Related Rock through Time

Project leaders: Roberto Dall'Agnol (Brazil), Carol D. Frost (USA), O. Tapani Rämö (Finland)

Duration: 2005-2009

No. 511 Submarine Mass Movements and Their Consequences

Project leaders: Jacques Locat (Canada), Juergen Mienert and Roger Urgeles - (IOC link)

Duration: 2005-2009

No. 512 Neoproterozoic Ice Ages Project leaders: Emmanuelle Arnaud (Canada), Marly Babinski (Brazil), Yves Goddéris (France), Galen Halverson (France), Martin Kennedy (USA), Conall Mac Niocaill (UK), Vibhuti Rai (India), Graham Shields (Australia), Maoyan Zhu (China)

Duration: 2005-2009 
No.513 Karst Aquifers and Water Resources

Project leaders: Chris Groves (USA), Yuan Daoxian (China), Bartolome AndreoNavarro (Spain), Heather Viles (UK) Duration: 2005 (-2009)

No. 514 Fluvial Palaeosystems: Evolution and Mineral Deposits

Project leaders: N. Patyk-Kara (Russia), A. Duk-Rodkin (Canada), Baohong HOU (Australia), Ziyang Li (China), Vladimir Dolgopolov (Kazakhstan)

Duration: 2005-2009

No. 515 Coastal Vulnerability related to Sea Level Change

Project leaders: U. Simeoni (Italy), Maria Snoussi (Morocco), Zdravko Belberov (Bulgaria), François Sabatier (France)

Duration: 2005-2009

No.516 Geological Anatomy of East and South East Asia

Project leaders: Ken-ichiro Hisada (Japan), Punya Charusiri (Thailand), Byung-Joo Lee (Rep. of Korea), Xiaochi Jin (China)
Duration: 2005-2009

No. 518 Fluvial Sequences as Evidence for Landscape and Climatic Evolution in the Late Cenozoic

Project leader: David Bridgland (UK)

Duration: 2005-2009

No. 519 Hydrogeology, Hydrochemistry and Management of Coastal Aquifers on the Atlantic Coast of South America

Project leader: Emilia Bocanegra

(Argentina)

Duration: 2005(-2009)

No. No. 521 Black Sea Mediterranean Corridor during the Last 30 ky: Sea Level Change and Human Adaptation Project leaders: Valentina Yanko-Hombach (Canada), Yucel Yilmaz (Turkey), Pavel

Dolukhanov (UK)

Duration: 2005-2009

No.522 Dawn of the Danian

Project leaders: Jeffrey D. Stilwell (Australia), Claudia Del Río (Argentina)

Duration: 2005-2009
No. 523 GROWNET - Gobal Ground Water Network

Project leaders: Shrikant Daji Limaye

(India), Dr A J Reedman (UK)

Duration: 2005 (-2009)

Funded projects

O.E.T.

Total

updated 24/02/05

\section{IGCP Secretariat}

UNESCO, Division of Ecological and Earth Sciences

1, Rue Miollis

75732 Paris Cedex 15

FRANCE

Tel: +33145684118

Fax: +33145685822

E-mail:igcp@unesco.org

\section{Episodes is your window to the world. Subscribe today!}

\section{Episodes}

\section{Subscription Order}

Name (please print)

Address

City State/Prov.

Country Zip/Postal Code

Please begin my subscription:

$$
\begin{array}{llll}
\text { March } & \text { June } & \text { Sept. } & \text { Dec. } \\
\text { Year } & \text { Year } & \text { Year } & \text { Year }
\end{array}
$$

To start your subscription, fill in this form and mail to:

\section{Episodes}

P.O. Box 823

26 Baiwanzhuang Rd.,

Beijing 100037, China

Tel: +86-10-6832 0827; +86-10-68329084

Fax: +86-10-6832 8928

E-mail: episodes88@yahoo.com
Payment may be made by:

- Checks (US \$ only) made payable to Episodes

- $\square$ Diners $\square \mathrm{JCB} \quad \square$ Visa $\square$ American Express $\square$ Mastercard

Please quote account number, expiry date and signature.

Account\#

Expiry date

Signature

Annual subscription rates: US\$24 